\title{
Ideological and Political Exploration and Practice of Aircraft Structure Design Course
}

Jia Yu

Harbin Engineering University, Harbin 150080, Heilongjiang, China. E-mail: yujiaworld@163.com

Funded Project: National Natural Science Foundation of China (51672054)

Abstract: In the modern society with the rapid development of economy and technology, the aircraft structure design course is gradually concerned. The ideological and political education in aircraft structure design is not perfect. For the ideological and political exploration of transferred students, we need to pay more attention to the outlook on life, values and other aspects. It is necessary to apply the relevant elements of ideological and political education in the aircraft structure design course, in order to establish the correct learning concepts, which are beneficial to students' philosophical analysis ability, activity and philosophical problem-solving ability. Firstly, this paper summarizes the current situation of ideological and political exploration of aircraft structure design course, analyzes the deficiencies and problems existing in the ideological and political education of aircraft structure design course, and puts forward countermeasures and practical plans, so as to integrates the correct ideological and political elements into professional courses teaching, and enhances the talent system and culture cultivation in colleges and universities.

Keywords: Aircraft Structure Design; Ideological and Political Course; Current Situation; Method

With the continuous advancement of education reform, the exploration of ideological and political course can not be ignored in the process of teaching and educating people in institutions of higher learning, which is also the core point for realizing teaching program reform in China. Aircraft structure design is a highly professional course. In the process of professional guidance for students, carrying out ideological and political work not only helps students learn professional knowledge, but also understand the craftsman spirit and patriotism of aircraft structure design ${ }^{[1]}$, so as to cultivate professional talents with excellent quality, professional quality and professional ethics, as well as make students better adapt the social needs.

\section{Current situation of ideological and political exploration for aircraft structure design course}

Aircraft structure design course is an important part of engineering construction in colleges and universities, which provides many professional talents for national industrial development. Aircraft structure design course creates an important foundation for the development of engineering technology and aviation industry in the aircraft structure design course. In the modern teaching environment, the traditional ideological and political exploration work is not ideal, many teaching teams still focus on professional knowledge and technical practice, ideological and political education has not been paid attention to ${ }^{[2]}$. General secretary Xi Jinping, at the National Conference on ideological and political work in colleges and universities, called

Copyright(C) $2020 \mathrm{Jia}$ Yu

doi: 10.18686/ahe.v4i10.2934

This is an open-access article distributed under the terms of the Creative Commons Attribution Non-Commercial License (http://creativecommons. org/licenses/by-nc/4.0/), which permits unrestricted non-commercial use, distribution, and reproduction in any medium, provided the original work is properly cited. 
for the continuous strengthening of ideological and political courses in colleges and universities, not only to cultivate students' psychological and ideological and political growth, but also to constantly excavate the ideological and political elements of knowledge in different specialties, so as to integrate education with professional knowledge rather than separate ideological and political education. Taking the aircraft structure design course as an example, the aircraft structure design course actively responds to the national "new engineering construction" talent training plan. In education and teaching, knowledge base of relevant professional knowledge should connect the aircraft structure design course with national strategy and aerospace industry etc., in order to better carry out the ideological and political exploration of aircraft structure design course.

\section{Deficiency of ideological and political education in aircraft structure design course}

Aircraft structure design course is the main course in aerospace, involving a lot of teaching contents. Students' employment positions are closely related to professional knowledge. With the complex teaching content, the requirements for students' professional skills are also very high. In order to improve students' learning quality, many colleges and universities focus on practical exploration, technical training for teaching guidance ${ }^{[3]}$, but moral education is often ignored, the cultivation of students' values is not included in the teaching task, especially the ideological education of Marxist philosophy, core values of socialism with Chinese characteristics, etc. The deficiency course arrangement causes low enthusiasm, lack of reasonable teaching plan, and ideological and political exploration work is not in place. Professional knowledge and professional quality, moral education are completely separated, the low connection between the three results in the low participation in moral education by the students.

In the aircraft structure design course, the structure composition, operation principle, system function, structural design and maintenance of aircraft are directly linked to the front-line work content. However, there is a lack of course training for students' duty style and moral quality in ideological and political education. In addition, students majoring in aircraft structure design need to participate in team cooperation in their future work, so as to better adapt to the job requirements. Therefore, another important content of ideological and political exploration is to strengthen the cultivation of students' team cooperation ability and hard-working spirit, and integrate professional knowledge, professional quality and ideological and political teaching into one, so as to realize optimization of the aircraft structure design course.

\section{Favorable factors of ideological and political exploration in aircraft structure design course}

First of all, in the aircraft structure design course, it contains a wide range of knowledge points, from structural knowledge to engineering mechanics, from control theory to material science. It is a multi-disciplinary course, for each teaching content can be integrated with ideological and political elements for education and teaching. Combined with the Marxist thought, ideological and political work is gradually infiltrated into students' daily courses, so that the relevant knowledge points can be gradually received by students; Secondly, the students of aircraft structure design course have adult wisdom, mature mental state, objective and fair thinking ability. In the process of learning aircraft structure design course, they have the ability to understand theoretical knowledge, and have a good ability to achieve mastery through a comprehensive study of the subject. They also have high efficiency to accept ideological and political elements without repeated guidance; Finally, with the continuous improvement of colleges and university resources in our country, the aircraft structure design course has many advanced teaching materials and teaching technologies, and the equipments and aircraft technology used in the major are also constantly absorbing new technologies. This also enables students to feel the motherland's painstaking efforts in talent cultivation, maintain the belief of serving the motherland, and actively study the experience of predecessors. Keeping good scientific research enterprising consciousness and strict self-discipline are of great benefit to the working state for students after graduation。

\section{Practical measures of ideological and political exploration in aircraft structure design course}

\subsection{Constantly integrating and understanding the ideological and political content in teaching process}

Teachers play an important role in ideological and political education. They also need to integrate professional ideological 
and political content into lesson preparation, which also raises the requirements for teachers' ideological and political theory. As a professional teacher of aircraft structure design course, they need to constantly consult professional technical literature, understand daily current affairs and politics, so as to follow the trend of the times and changes in thinking. The application of new teaching methods makes comprehensive analysis for Marxism, socialism, flight culture etc. In the teaching process, professional political comments are given, and the new and interesting ideological and political content are explored from the network, so as to enhance students' interest in learning and teaching efficiency.

\subsection{Leading students to discover the ideological and political elements in the aircraft structure design course}

There are rich ideological and political elements in the aircraft structure design course, such as the theoretical knowledge of aircraft structure design can be associated with love of post and dedication; the practical experience used in professional courses can be related to predecessors and scholars' hard-working and conscientious spirit in the research and development of technology; and the aircraft structure design needs continuous team efforts, including sincerity and friendliness of ideological and political elements. Generally speaking, aircraft design course is not limited to theoretical and technical education within the major, but can guide students to divergent thinking and ideological and political education, so that students can feel how to develop good working quality in the learning process. More importantly, it is necessary to establish a correct outlook on life and values in the learning process, and strengthen the ideological and political construction for aerospace specialty.

\subsection{Constantly applying new teaching methods for ideological and political education}

The students of aircraft structure design have a strong ability of independent thinking and learning. The traditional teaching methods are not suitable for the needs of contemporary students. By applying "micro class" and ideological and political education group activities, students no longer listen to the knowledge of ideological and political passively, but let students discover the content of Ideological and political education independently in the course of aircraft structure design with appropriate explanation and guidance by teachers. We should flexibly use the ideological and political elements. For example, when learning the spiral rising knowledge points of aircraft structure design, combined with the materialist dialectical theory, the equipment and structure are explained to the students. The performance changes of aircraft in different states and different use conditions, combined with knowledge of Marxist theory of, students imperceptibly understand the content of ideological and political education. In addition, we can combine classic cases and heroic deeds in the history of aviation and astronautics with relevant videos and commentaries to sublimate students' thoughts, so as to firmly follow the guidance of the party, and closely connect professional knowledge with the construction of socialism with Chinese characteristics.

\section{Conclusion}

The ideological and political education in the course of aircraft structure design should be combined with the concept of teaching and educating people. The core of ideological and political education is to cultivate students' good morality. The concept of ideological and political education needs to be integrated into the aircraft structure design course. It is also necessary to start from the details and change the traditional ideological and political teaching methods through the joint efforts of schools, teachers and students, and encourage students to explore and participate in thinking by themselves in ideological and political exploration, in order to improve the quality of teaching.

\section{References}

1. Hou C, Zhao M, Huijia, et al. Exploration on the construction of aircraft structure design course group for new engineering. Journal of Northwest University of Technology Social Science Edition 2017; (4): 86-90.

2. Zhao L, Zhang J. Application of digital teaching in the course construction of aircraft structural dynamics. Proceedings of 2018 Third International Conference on Education Technology and Training(Volume 8); 2010.

3. Zhao L. Exploration and practice of aircraft structural dynamics course construction. Mechanics and Engineering Application; 2010. 